\title{
Impacts of Job Stress and Overall Compensation Benefits on Employees' Job Satisfaction with Moderation Effect of Leadership: An Empirical Study in the Telecommunication Industry of Cameroon
}

\author{
Hongyun Tian, Brice Berinyuy Fonjong* ${ }^{*}$, Maxwell Kongkuah ${ }^{\circledR}$, Richard Barfi \\ Jiangsu University, Zhenjiang, China \\ Email: twfh7522@163.com, ^fonjongbrice@gmail.com, maxwellkongkuah@outlook.om, richiebarfs@yahoo.com
}

How to cite this paper: Tain, H. Y., Fonjong, B. B., Kongkuah, M., \& Barfi, R. (2021). Impacts of Job Stress and Overall Compensation Benefits on Employees' Job Satisfaction with Moderation Effect of Leadership: An Empirical Study in the Telecommunication Industry of Cameroon. Open Journal of Business and Management, 9, 44-73.

https://doi.org/10.4236/ojbm.2021.91003

Received: September 23, 2020

Accepted: December 15, 2020

Published: December 18, 2020

Copyright $\odot 2021$ by author(s) and Scientific Research Publishing Inc. This work is licensed under the Creative Commons Attribution International License (CC BY 4.0).

http://creativecommons.org/licenses/by/4.0/

\begin{abstract}
Background: Nowadays, existence of self-motivated and efficient human resource is a key issue of great importance in the telecommunication industry. Considering that human resource in an organization is significant resources, steps should be taken to find the strong and weak points in enhancing the operation of increasing efficiency in the firm. Moreover, job satisfaction has been considered one of the important factors in the provision of superior performance and high quality services at the telecommunication industry. Problem: Considering the telecommunication industry that is one of the primary industries in the poor performing sector of Cameroon. An industry is growing at high speed by adopting unfair practices. Operators are not satisfied with the current government regulations towards issuance of SIM's and the imposition of XAF 3.5 billion fine. Purpose: This study aimed to explore the impacts of job stress (JS), work environment (WE), overall compensation benefits and pay (OCS), leadership, and moderating role of leadership on employees' job satisfaction (EJS). Method: A quantitative method was employed in the sample size of 515 responses. A technique of random sampling was used to select the respondents. Data was collected through a field survey by using a closed-ended questionnaire. The analysis was done through SmartPLS 3.0. Results: The results have supported the hypothesized model. Indeed, findings proved a significant relationship between JS, WE, OCS, leadership, and EJS. Leadership significantly moderates the relationship between JS, WE, OCS, and EJS. In particular, job JS has adverse effects on EJS. Originality/Value: This paper helps the executives of telecommunication industry how
\end{abstract}


to lessen the job stress and increase the level of job satisfaction. This paper has implications for practitioners and researchers interested in examining the moderating role of leadership on employee's job satisfaction. As well as work environment plays a critical role in the satisfaction of employees.

\section{Keywords}

Job Stress, Work Environment, Overall Compensation Benefits and Pay, Leadership, Employees' Job Satisfaction

\section{Introduction}

In today's dynamic world, all sizes/kinds of organizations, operating in developed or developing countries, involved in the race of struggling to become successful and leader in their respective industries, and to sustain growth and development (Eikelenboom \& de Jong, 2019). An environmental dynamic didn't only affect and generate pressure for the organizations, often all of the stakeholders involved in generating value (Borgwardt et al., 2019), employees (Karimi, 2019), and suppliers (Eiriz \& Carreiras, 2018).

(Locke, 1976) defined it as "the pleasurable emotional state which employees derive from accomplishing tasks" or receiving a reasonable incentive. It is a collection of attitudes that employees develop about their jobs and their related tasks (Lee \& Moon, 2011). According to (Chung et al., 2017), job satisfaction is a crucial construct to know about employees' insights on how their enterprises cure them. It has been connected to several "behavioral, mental, and physical health, and organizational outcomes, customer satisfaction, and productivity" (Tomaževič et al., 2014). The job situation and employees' attitude towards the job defines typically his/her job satisfaction. It is one of the critical factors as well as a problem for the service-providing sector to retain and hold talented and competitive employees (Kakada \& Deshpande, 2019).

Moreover, EJS can be influenced by incentive (Chinyio et al., 2018); transformational leadership (Boamah et al., 2018); ethical leadership (Attar et al., 2017); working conditions/environment (Ashraf, 2019) participative leadership (Chan, 2019); workloads (De Simone et al., 2016); organizational and leadership career management (de Oliveira et al., 2019); stress (Halkos \& Bousinakis, 2017); job and organizational characteristics (Jin et al., 2018).

Psychology, management, and sociology are amongst several disciplines involved in the examination of job related stress (Trivellas et al., 2013). Overall, they largely coverage that stress mainly impacts productivity and performance of the firms. Numerous factors of JS have been recommended in the existing literature such as workload, management style, physical environment, working relationship, work itself, career development, rewards, job security, role conflict and ambiguity, and job autonomy (Lu et al., 2012). In particular, JS usually im- 
pacts organizational and individual issues comprising, mental, behavioral, as well as performance, physical outcomes, organizational commitment and engagement, and job satisfaction (Beheshtifar et al., 2011). Modern firms consider JS and job satisfaction of their subordinates as two critical workplace issues (Lee et al., 2015). Job related stress is considered harmful when emotional and physical responses incur when there is a misfit among job requirements and the employees' capabilities, needs, or resources. Prior scholars, investigated the correlation between JS and job satisfaction (Lambert et al., 2018), and corroborate that high level of JS linked with low level of job satisfaction (Khalatbari et al., 2013). Understanding the link among JS and EJS becomes significant particularly for Cameron telecom industry where employees and organizations experiencing the adverse effects of government regulation and imposition of penalties. Most of the studies to date have focused on the influences of work stress in the nursing environment and in hospital context (Khamisa et al., 2017), however, this study fills the gap of JS-EJS relationship in telecom industry.

The physical form of WE is space, noise, physical layout, materials, tools, and co-workers association; the quality of all of such facets has significant and positive effects on the quality of work performance (Pawirosumarto et al., 2017: p. 1339). WE is a place where subordinates perform their activities, where it can bring negative and positive impacts for the employees to accomplish their goals. A conductive WE has a positive effect on continuity of employment, in contrast, less conductive has a negative. (Zhang et al., 2014) stated that when employees having good WE were less likely to report job dissatisfaction, high burnout, and intention to leave comparative to poor WE, and conclude that improving WE could be an effective strategy for job outcomes. According to (Agbozo et al., 2017), a supportive and attractive WE is one of the critical factors to job satisfaction. Authors classified the three form of WE; physical includes (office layout, machinery, lighting, temperature, and ventilation), psychological (affect based-emotions, affective disorder, moods; cognitions-attitude, decision making, perception; and behaviors-motivation, absence, and effectiveness), and social deals with relationship at job setting. Most importantly, fostering and creating supportive WE is essential, where the working condition presents several challenges. Though a large number of scholars have focused on employees' job outcomes and have revealed how it becomes associated with supportive WE (Kim et al., 2018), the evidence from developing countries specifically Cameron is limited. There is no study on link between WE and EJS with large sample across Cameron.

The compensation benefits and pay are considered the main reasons for the satisfaction of employees, and one of the ways to sustain potential employees is to provide them attractive and adequate compensation in accordance with their preferences, needs, and performance (Pepra-Mensah et al., 2017). Also, (Afrizal 2012) confirmed that compensation has significant effects on EJS. Whereas some of the scholars stated that compensation is not driver for EJS. As these are basic 
needs of employees, where their lower level can increase dissatisfaction (Stamolampros et al., 2019). Thus, a debate is continuing both compensation can influence the EJS, and how it could. Hence, this study employed compensation benefits and pay in the context of Cameron.

Human capital provides a competitive edge due to innovativeness; thus it is considered one of the resources that support the mission of firm (Holland et al., 2007). The value of human resource in firm performance is grounded on several factors. Some of them are directly or indirectly regards to leadership style and organizational culture. The increased competition due to scarcity of resources, calls for more strategic methods by organizational leaders and managers to the task satisfying their subordinates and enhancing their satisfaction, work motivation and commitment Leadership is a complex phenomenon, effected by relationships, personalities, circumstances, relationships, and other factors within job setting (Al-Sada et al., 2017). The prior researcher pinpoints the importance of leadership to work performance (Bortoluzzi et al., 2014), and job satisfaction (Muzailani et al., 2019). Indeed, to the overall satisfaction employees evaluate career opportunities, compensation and benefits, senior leadership, work-life balance of the company (Stamolampros et al., 2019). This study adds value to the existing literature by focusing on moderating role of participative leadership in telecommunication industry.

\section{Telecom Industry Performance in Cameron}

Globally, in 2016, the telecommunication industry specifically mobile phone companies, and service operators contributed $4.4 \%$ to GDP, equivalent to approximately $\$ 3.3$ trillion of economic value. They were predicted that it might increase to greater than $\$ 4.2$ trillion, which is around $4.9 \%$ of GDP by 2020 (Harris, 2018). Telecom regulatory agency (TRA) reflected that out of 22 million subscribers 16.8 million, 93.8\% subscribers are in the basket of MTN and Orange. MTN has a $57.04 \%$ market share, and $36.8 \%$ are with Orange (Yaoundé, 2019). The Cameroon government continuously provides support to MTN and Orange as $95.0 \%$ of all the transactions carried from the platform of both providers, 3.3\% revenue of the sector increased in 2017. In support, the "Cameroon Digital 2020" program launched by the government aimed to provide connectivity throughout the country (Lancaster, 2019).

A 20-year experienced audit company on October $27^{\text {th }}$ presented reports to the public in the presence of Minette Libom Li Liking (Minister of post and telecommunication). Reports revealed that the service qualities of all operators' are not up to the standards, due to their non-compliance and poor quality of technical support (Audit for the Ministry of Post and Telecommunication (Minpostel) in Cameroon, 2017). Orange declared that due to the increase in strictness of government regulations for customer identification, the initial registration process and hyper-competition market share grew up by $4.6 \%$, which is less than the previous year. It involves a decrease of 1.2 million subscribers due to the go- 
vernmental regulations and industry competition (Welcome to Orange Cameroon, 2017). The XAF 3.5 billion imposed as elegant on Orange, MTN, and Nextel for not following the standards of regulation, involved in the unwanted practice of selling and activating sim cards without prior registration, and identification (Donkin, 2019).

As the aforementioned literature exhibited that external environments, comprises of government regulations, industry competitions, and customer's negatives views, affect the revenues and the market share of the operator. To cope up with continuous changes in external factors, companies' internal environment will be infected, which increases job stress to save potential customers and bring new subscribers. Henceforth, to boost up the performance of internal stakeholders, companies focus on their work environment and overall compensation and benefit. More specifically, previous studies also used the leadership style to moderate the relationship between constructs used (González-Navarro et al., 2018). In addition, the leadership role of executives eventually upsets employees' performance (Scully et al., 1995), commitment towards enterprise (Huang et al., 2006) and job performance (Smylie et al., 1996). Therefore, we employed this study, which aims to investigate is there any correlation of JS, WE, OCS, L, and EJS in the telecom industry of Cameron.

\section{Literature Review}

\subsection{Theoretical Support}

\section{Hygiene-Motivation-Theory (HMT)}

Frederick Herzberg is well-known for new-concepts and idea in the social sciences such as the "workplace motivation, kick in the ass (KITA) and job enrichment". Though, he is well-known for his HMT, which was published in 1959. His work was largely dedicated to the inspiration of individual employees/workers in the workplace. Still, it had become extremely general with executives, as it also highlighted the significance of "management knowledge and expertise." The HMT is also known as the two-factor-theory. He examined "employees' attitudes to their works along with their stimulators that impact on the motivation of an individual to work". He scrutinized the number of factors/antecedents in which employees to be satisfied. Hence, He came to a close that every person has two "sets of needs-lower level of needs as an animal to avoid pain and deprivation and a higher level of needs as a human being to grow psychologically". Thus, few of the influences in the workplace environment satisfy the first tier of needs and little in the second. Then he classified and grouped them into Hygiene factors and motivators.

In addition, He has given the concept of KITA to elucidate why executives become unwilling to inspire workers. Herzberg displayed that "employees are not motivated by being kicked or by being provided more money or benefits, a comfortable work atmosphere or reducing the time spent at work". He denoted such components as "Hygiene factors or satisfiers", which are based on the cir- 
cumstance or the milieu in which an individual works. Furthermore, he elucidated that those factors are organization policies and regulations, leadership and supervision, interactive relations, compensation, benefits, and pay security and insecurity related to the job, status and personal life, and working environment. These influences are not for endorsing satisfaction of a job, nonetheless for aiding mainly to avert dissatisfaction of the job. For example, "good hygiene does not produce good health by itself, but the lacking of it may cause disease". He also says about them as dis-satisfiers or care factors, as if "it is their absence or inadequacy, which causes dissatisfaction at work". Therefore, few drivers are not accurate motivators, as they essentially continuous support.

In these circumstances, inherent motivation stagnant only with the executives, while the employees are simply being constrained to act to escape penalty or gain compensation. Moreover, the recompenses progressively come to be regarded as privileges to be probable, slightly than enticements to superior satisfaction and accomplishment. "Motivators also referred to as growth factors-relate to what a person does at work, rather than to the context in which it is done". They comprise career growth, accomplishment, recognition, level of responsibility, the work itself. The author elucidates that both factors are different as it's pertinent to a different group of needs. They are not opposites. HMT recommended that motivators related to job satisfaction and hygiene to job dissatisfaction. HMT is imitative from the results of numerous inquiries into employees' job satisfaction and dissatisfaction; these are simulated from his "original research in Pittsburgh". Additionally, most of the confirmation on which he built his theory is pretty clear cut. This is principally the case relevant to the attainment and promotion prospects as "potential job satisfiers and concerning supervision and job insecurity as factors which contribute principally to dissatisfaction".

Not only this, when an individual exerts more effort and accolades with low rewards, but it also leads to greater levels of stress (De Jonge et al., 2000). HMT has been recycled in several different studies in the human resource management prose. The furthermost fresh educations are (Velmurugan \& Sankar, 2017; Filtvedt, 2016; Matei \& Abrudan, 2016). Many studies deal with different factors of two-factor theory, such as the moderating effect of support on employee well-being (Guidetti et al., 2018), mediating effect of person-organization fit on workplace spirituality (Afsar \& Badir, 2017), moderating impact of supervisor support and job control on organizational change (Day et al., 2017), emotional culture (Barsade \& O’Neill, 2016), green atmosphere and job satisfaction (Başol, 2016), and job satisfaction (Monga et al., 2015).

\subsection{Hypothesis Development}

\subsubsection{Job Stress and Job Satisfaction}

(Selye, 1964) has define stress as “an individuals' material as well an emotional reaction to potentially threatening aspects of the environment". On the whole, 
job stress is "a situation for an individual when the job issues force an individual to alter, modify or revolutionize his (her) mental and emotional state in such a manner that the individual is forced to deviate from their normal working behavior” (Beehr \& Newman, 1978).

In today's era of a dynamic world, everyone is struggling to fulfill their dreams within limited resources. Likewise, enterprises' are facing difficulties due to scarcity of resources, an increase in competition, and continuous changes in the internal and external environment. Though such conditions push the organization in a well, where firms demand more work from their employees. While employees are found in a state of burnout, unsatisfied, and overloaded with their work. (Khalatbari et al., 2013), a study of a sample of 160 employees' found the association between job stress, job satisfaction, and job motivation. (Singh \& Nayak, 2015) conducted a quantitative study of a sample of 599 police officers in India. Scholars founded the negative relationship between job stress and job satisfaction. Conclude that to decrease the level of job stress and improve job satisfaction of the police officers there is a need to clarify employees' responsibilities, task objectives and providing them performance feedback.

Prior research exhibited that job stress is the dominant antecedent of job satisfaction (Makola et al., 2015; Zulfiqar et al., 2013). (Khamisa et al., 2017; Khalatbari et al., 2013), conducted a study of a sample of 895 nurses, found that personal stress is the dominant predictor of "burnout and health than job satisfaction." Prior research confirmed that productivity of both organizations and employees impacted by two factors, stress and satisfaction of employees (Halkos \& Bousinakis, 2017). The authors proved that increase in the level of stress leads to a decrease in performance, increased the improvement in the satisfaction of employees leads to a rise in productivity. Nowadays, most of the organizations in developing countries struggling to have control of both factors. If both functions well, positive results can be expected for employees' work and for the organization. Hence, we suggested following hypothesis:

$\mathrm{H1}$ : Job stress has negative and a significant effect on employees' job satisfaction.

\subsubsection{Work Environment and Job Satisfaction}

Insights of a positive work environment-for instance, a place with better psychological and physical environments/circumstance, in addition to prospects for the balance of work-life-to bring out the finest in personnel and surge their promise, loyalty with work, organization, and performance. A review study of (Wei et al., 2018), from the beginning of 2005 to the end of 2017, aimed to know the major concentrations behind prior studies related to the nurse's work environment in the United States. Scholars conclude that employees at the front line are the basis for proving the quality and safety of care and services. Supporting nurse consent, involvement, commitment, and interactive relations at work is significant to attain and sustain a vigorous level of quality services, care, and 
work environment. The results of healthier work environments primes to more satisfied front line employees and nurses who will result in superior job performance, patient care, and quality of services.

(Langer et al., 2019), investigation of the centralized bureaucratic and entrepreneurial work environment, displayed a negative relationship of work environment on job satisfaction and noted the positive indirect effect of entrepreneurial work environment on job satisfaction. (Pawirosumarto et al., 2017), a study of 642 employees of hotels and resorts in Indonesia found a positive association between work environment, organizational culture, leadership style, and job satisfaction. (Gacevic et al., 2018) conducted the cross-sectional study in the Siberian public health sector sample of study includes 73,940 respondents. The results of the study reveal that there is a direct influence of working conditions on job satisfaction. The authors conclude that poor management and working conditions are the main factors behind the dissatisfaction of employees in the health sector. In addition (Dutra et al., 2018), also confirmed the positive association of work environment with job satisfaction. Authors reported that out of 450 surveys, $28 \%$ nurses claimed dissatisfaction because of poor working environment. Therefore, we proposed following hypothesis.

H2: Work environment has positive and a significant effect on employees' job satisfaction.

\subsubsection{Overall Compensation Benefits and Job Satisfaction}

(Peluso et al., 2017), the study adopted the approach of "(Lyons \& Ben-Ora, 2002)" he classified the total reward system into four heads 1) "Base pay it includes elements like base salary, variable pay, recognition, and stocks"; 2) "Benefits, include health care, retirement, savings and time off"; 3) "Training and development opportunities, include career development, performance management, succession planning and training"; 4) "Work environment, which includes intangible elements such as the organizational climate, leadership, performance support and work/life balance". Scholars showed a positive relationship with the total reward system with job satisfaction, affective commitment, and innovative work behavior. A qualitative study of (Suttikun et al., 2018), based on the context of Thailand, concludes that during the job, tangible benefits and intensive rewards towards a career apart from monetary benefits lead to job satisfaction. Employee engagement during offering services leads to the satisfaction of the customer, who return, thus enabling spa employees and firms to generate more income. (Spencer et al., 2016) a study of a sample of 848 showed discrimination among gender-based compensation benefits and pay. Scholars showed that female employees' are working equivalent to the male, though they are not getting and compensated alike. However, there is no difference in job satisfaction levels.

(Chinyio et al., 2018), a study of a sample of 260 respondents of Jigawa state public sectors, stated that compensation elements "salary; pension; gratuity; and bonuses" have a positive influence with "attraction; motivation; job satisfaction; 
and retention of the public sector". In addition, (Gulyani \& Sharma, 2018), the study proposed that total reward systems have a strong influence on the personnel's work engagement and happiness at work. Specifically, the pay is considered one of the key factors and individually equivalents four times compared to other compensation factors (Addis et al., 2018). Moreover, (Lim et al., 2019), also founded the positive influence of extrinsic rewards on employees' job satisfaction and person-organization fit. Therefore, we proposed the following hypothesis:

H3: Overall compensation benefits have positive and statistically significant effects on employees' job satisfaction.

\subsubsection{Leadership and Job Satisfaction}

Over the decades, researchers have paid attention to participative leadership and its effects on job satisfaction. Leaders possessing participative characteristics share responsibility for decision making with subordinates (Benoliel \& Barth, 2017). This type of leadership behaviors aimed to indulge employees in problem solving and decision making, to provide employees with personalized support, and to pay particular attention to employees (Nystrom, 1990). It therefore ultimately influences the employees' job satisfaction (Chan, 2019), organizational commitment (Miao et al., 2013), and quality of work file (Dhamija et al., 2019). Indeed, the prior work has highlighted the significance of participative leadership to employees work performance (Newman et al., 2016). Besides, scholars have shown that positive mood and job beliefs increase the employee's job satisfaction (Ilies \& Judge, 2004). When subordinates feel that they are performing better task that contributes to the success of their firms, they are more energetic to work, and experience greater level of satisfaction as result of their accomplishing responsibilities. Therefore, this study proposed following hypothesis.

H4. Leadership positively and significantly affects employees' job satisfaction.

\subsubsection{The Moderation Effects}

Empirical studies have investigated the effects of participative leadership on work performance and the mediating processes (Newman et al., 2016). In particular, the influences of participative leadership on job satisfaction has received more attention, little work is directed to investigate the moderation of participative leadership. (Jin et al., 2018) conclude that job stress can be reduced with supervisory support, role clarity, coworker integration, and agency formalization. (de Oliveira et al., 2019) study based on the context of Brazilian organizations reflected that career management and leadership career support influence the satisfaction of a job and turnover intension. Moreover, the authors noted that leadership support moderates the link between organizational career management practices and job satisfaction and turnover intension. (Boamah et al., 2018) investigated the direct influence of leadership on workplace environments and noted positive impacts on job satisfaction. Also, (Chan, 2019) found the positive impact of leadership on employees' job satisfaction and consider one of the key 
factors for promoting work engagement. A focus on emerging booming leadership abilities amongst nurse leaders' hospitals will progress the formation of "healthy work environments" that endorse employees' job satisfaction and the retention of employees' (Bawafaa et al., 2015). Also, (Attar et al., 2017), a municipality of Kenya based a study of a sample of 224, showed the positive direct relationship of ethical leadership behavior with job satisfaction.

Leadership also used as a moderator in previous studies of (Zheng et al., 2019; Hussain \& Younis, 2015) between envy and counterproductive work behavior (González-Navarro et al., 2018); between intragroup conflicts and teamwork, quality (Curşeu, 2011); between strategic human resource practices and job satisfaction (Hamid \& Azhar, 2015); between management control and business excellence (Doeleman et al., 2012); between follower characteristics and follower work engagement (Zhu et al., 2009). Thus, we suggest the following hypothesis:

H5: Leadership moderates the relationship between (a) job stress; b) work environment; c) overall compensation benefits and pay] and employees' job satisfaction.

\section{Research Methodology}

\subsection{Sample and Data Collections}

This scholarship targets all levels of employees' working in the telecommunication industry of Cameroon, the main reasons behind the telecom industry comprises the prior scholar has done 1) little work. 2) Continuous poor performance of the sector and just $0.6 \%$ contribution to the GDP of the country. 3) Observed the stress among employees because of increasing restrictions and imposition of penalties, and opposing results of an audit report. 4) Current government fluctuations in policies and regulations related to security and steps taken towards blocking of SIM's again create the situation of job stress. Particularly, in Cameroon, there are four telecommunication operator MTN (South African based multinational mobile telecommunication company), Orange (French multinational telecommunications corporation), Viettel (State-owned enterprise), and Camtel (state-owned company) provides the internet services and digitization of the telephone (TELCOMA, 2019). A closed-ended questionnaire administered, which include six sections. First section reserved for respondents general information. While the rest of the five sections include questions related to the constructs. Data were collected throughout the country from January 2019-June 2019. Initially, two pilot tests conducted on observation of 50 - 50 respondents as a means of that checking questions work as intended and are understood by those individuals who are likely to respond to them and to reduce sampling error and increase questionnaire response rates. The pilot test showed that random sampling was best for the study as our questionnaires were easily understood by our target respondents. After that, the collection of data started at a large scale, 540 questionnaires distributed from which 530 received back, 15 questionnaires 
removed from the analysis because of insufficient information provided. Hence the response rate of the study was $98.15 \%$. A sample of 540 was chosen to increase the precision of the result as the number employees in the telecommunication sector of Cameroon span over 2500 employees. A technique of random sampling adopted to select the respondents. The questionnaire includes 39 items related to the constructs. Therefore, based on structural equation modeling and previous scholars, the sample size should be $10 \times$ to the items used in the study. Though, to better know the insights of respondents, we have opened the gate for them and try to accumulate more responses. Therefore, this study involves the sample size $(\mathrm{N}=515)$.

\subsection{Demographical Information}

Table 1 exhibits the demographics information of respondents. A sample of 515 employees' represents the population of the telecommunication sector in Cameroon. 392 (76.1) of the respondent are male, followed by $123(23.9 \%)$ are females. In addition, $246(47.8 \%)$ of the respondents are falling in the range of 31 40 years, followed by 219 (42.5\%) in 20 - 30 years. From an education perspective, 291 (56.5\%) respondents are having a master's degree, followed by 216 (41.9\%) graduation, and remaining (1.6\%) have more than the master. Furthermore, 253 (49.12\%) of the respondents are having a job in the sales and marketing department, followed by $209(40.6 \%)$ selected another option, apart from the HR and Finance department. As work experience, 260 (50.5\%) of the respondents have 5 - 10 years' experience, followed by 127 (24.7\%) 1 - 5 years and (24.8\%) $11-15$ years. As mentioned in the table below, 228 (44.2\%) of respondents have more than 60,000 rupees salary. Out of 515 respondents, 333 (64.7\%) are married, and the remaining $182(35.3 \%)$ are single.

\subsection{Measurement Scales}

Work environment, assessed by seven items, taken from the study of (Qureshi et al., 2012). This scale was adopted because it has been successfully used in previous studies (Pawirosumarto et al., 2017; Langer et al., 2019). Job satisfaction, assessed by 4 item scale adopted from the study of (Thatcher et al., 2002), and successfully administered in recent studies (McVeigh et al., 2019; Lim et al., 2019). Job stress was evaluated by seven items; these items were taken from the study of (Qureshi et al., 2012). The scale was adopted into this study because of its more excellent reliability witnessed in previous studies (Chung et al., 2017; Halkos \& Bousinakis, 2017). The scale of leadership adapted to form the study of (Chaiprasit \& Santidhiraku, 2011), scale comprises of 11 items. The scale items also used in recent studies (Boamah et al., 2018). While compensation benefits and pay measured by eight items taken from the study of (Munir \& Rahman, 2016). All the variants were reserved by using 5 -points Likert scale ratings $1=$ strongly disagree, 5 = strongly agree. 
Table 1. Participants Characteristics. Demographic Characteristics.

\begin{tabular}{|c|c|c|}
\hline Gender & Frequency & $\%$ \\
\hline Male & 392 & 76.1 \\
\hline Female & 123 & 23.9 \\
\hline Total & 515 & 100 \\
\hline \multicolumn{3}{|l|}{ Age } \\
\hline $20-30$ & 219 & 42.5 \\
\hline $31-40$ & 246 & 47.8 \\
\hline $41-50$ & 50 & 9.7 \\
\hline Total & 515 & 100 \\
\hline \multicolumn{3}{|l|}{ Education } \\
\hline Graduation & 216 & 41.9 \\
\hline Master's Degree & 291 & 56.5 \\
\hline Higher Than Master's Degree & 8 & 1.6 \\
\hline Total & 515 & 100 \\
\hline \multicolumn{3}{|l|}{ Department } \\
\hline HR & 35 & 6.8 \\
\hline Financial & 8 & 1.6 \\
\hline Sales \& Marketing & 253 & 49.12 \\
\hline Other & 209 & 40.6 \\
\hline Total & 515 & 100 \\
\hline \multicolumn{3}{|l|}{ Work Experience } \\
\hline 1 to 5 years & 127 & 24.7 \\
\hline 5 to 10 years & 260 & 50.5 \\
\hline 11 to 15 years & 128 & 24.8 \\
\hline Total & 515 & 100 \\
\hline \multicolumn{3}{|l|}{ Salary } \\
\hline Below 20,000 & 88 & 17.0 \\
\hline 40,000 to 60,000 & 199 & 38.6 \\
\hline Above 60,000 & 228 & 44.2 \\
\hline Total & 515 & 100 \\
\hline \multicolumn{3}{|l|}{ Marital Status } \\
\hline Married & 333 & 64.7 \\
\hline Single & 182 & 35.3 \\
\hline Total & 515 & 100 \\
\hline
\end{tabular}




\subsection{Analysis}

The analysis of results and model proved by using partial least squares, techniques of consistent PLS Algorithm, and bootstrapping. Structural equation modeling used for path analysis. The measurement model was tested and verified based on the reliability and validity of variables noted in recent studies. Both inferential and descriptive results were found and reported in the tables. The main reason behind the SmartPLS includes the wide popularity and acceptability of its application (Hair Jr. et al., 2012a; Kura, 2016). Furthermore, PLS is considered more comfortable, and one of the developed system (McDonald, 1996). However, this study involves mediation and moderation effects, which are the key aim of using this software (Ringle et al., 2015). Additionally, in recent days' most of the scholars prefer SmartPLS in all of the discipline (Qalati et al., 2019; Khoi \& Van Tuan, 2018; Tran et al., 2019; Sadalia et al., 2019; Umrani et al., 2018; Akter et al., 2017; Choshin \& Ghaffari, 2017).

\section{Results and Measurement Analysis}

This study employed Harman's single factor and full collinearity test to ensure data free from common method bias. Harman's singly factor test results show a single factor explained only $24.221 \%$ of the total variance, which is far below the 50.0\% (Podsakoff et al., 2003).

In addition, following the recent suggestions in the PLS-SEM literature and particularly (Kock \& Hadaya, 2018), this study employs the full collinearity approach, specifically variance inflation factor (VIF) for detecting evidence on CMB. The results of the study shown in Table 2 stated that CMB is not a key concern since the computed VIFs are less than three 5 (Hair Jr. et al., 2011). Again, following previous research (Jibril et al., 2020), the current work concludes that since a study that examines the presence of mediation effect, it is extremely difficult for respondents themselves to mentally manipulate. Therefore, the concerns about $\mathrm{CMB}$ are minimal here; hence in this analysis, the potential for $\mathrm{CMB}$ is low.

Before moving towards the analysis, this study used Kaiser-Meyer-Olkin (KMO) recommended to measure the sampling adequacy and to ensure the suitability of data. The KMO test result is 0.828 , which is greater than an acceptable threshold 0.50, and hence, consider substantial for explanatory factor analysis (Çetinkaya \& Karabulut, 2016; Chan et al., 2011). Moreover, Bartlett's test results reflect that the level of significance is at 0.000 and thus is consider good as it is below the 0.05 significance level. Only one item of the study removed from the model due to factor loading less than 0.7 recently suggested by (Hair Jr. et al., 2017).

\section{Measurement Model}

For results analysis, we have employed partial least square structural equation modelling (PLS-SEM). Several tests were conducted related to reliability, validi- 
ty, and path coefficients. Also to ensure the data free from multicollinearity and other data related bias were measured (Hair Jr. et al., 2010). The analysis section utilized a two-way approach to assess the results.

1) Assessment of measurement model and 2) Structural model (Hair Jr. et al., 2010).

\section{1) An assessment of the Measurement Model}

As per (Henseler et al., 2009) suggestions in order to measure the model of study scholars are required to assess the "individual item reliability, internal consistency, content validity, convergent validity, and discriminant validity".

Individual item reliability: Assessed through the outer loadings of items related to a particular dimension (Hair Jr. et al., 2012a). (Hair Jr. et al., 2016) recommended that it should be retained within 0.40 and 0.70 . As demonstrated in Table 2, all the values adequately satisfied and meet the standards, present study items retained between 0.724 and 0.901 .

According to (Nunnally, 1978), the value of Cronbach's Alpha (CA) should be greater than 0.7 . The values of CA retained between 0.774 and 0.941 . Therefore, it is concluded that the study adequately meets the standard of reliability of the measures.

Internal consistency reliability: (Bagozzi \& Yi, 1988) proposed that the value of composite reliability (CR) should be equivalent to or exceeds 0.7 . Table 2 exhibited the CR of the constructs, retained between 0.854 and 0.950 , proposing the adequate reliability of the measures.

Convergent validity: According to (Fornell \& Larcker, 1981), rule of thumb the value of AVE, should be equivalent to 0.5 or above. The value of AVE of the study, retained between 0.596 and 0.740 henceforth; it is concluded that this work qualifies the satisfactory level of convergent validity.

Discriminant validity: Two methods were used to evaluate the "discriminant validity" of the variables. 1) It was ensured that the cross-loadings of indicators should be higher than any other opposing constructs (Hair Jr. et al., 2012b). 2) According to the Fornell and Larcker (1981) criterion, the square root of AVE for each construct should exceed the inter-correlations of the construct with other model constructs". Therefore, as shown in Table 3, it could be concluded that all the constructs employed in the work have adequate level of discriminant validity.

\section{2) An assessment of the Structural Model}

This article utilized PLS bootstrapping with 5000 bootstraps and 525 cases with the motive to analyze the hypothesized model and its significance (Henseler et al., 2009). Figure 1 demonstrates the comprehensive illustration of assessments of the structural model alongside with statistics related to moderation of leadership.

Collinearity issue of structural model: To ensure the multicollinearity issue, editors and scholars require HTMT (Heterotrait-Monotrait) ratio, (Gold et al., 2001) proposed that value of the constructs should not exceed 0.9. Table 4 showed that the maximum value of a construct found 0.616 , henceforth this study is free from multicollinearity issue. 
Table 2. Measurement model evaluation.

\begin{tabular}{|c|c|c|c|c|c|c|}
\hline Construct & Items code & Loadings & $\mathrm{CA}^{1}$ & $\mathrm{CR}^{2}$ & $\mathrm{AVE}^{3}$ & Inner VIF \\
\hline \multirow{6}{*}{$\begin{array}{l}\text { Overall compensation } \\
\text { benefits \& pay }\end{array}$} & OCS2 & 0.833 & 0.903 & 0.925 & 0.672 & 1.252 \\
\hline & OCs3 & 0.795 & & & & \\
\hline & OCS4 & 0.846 & & & & \\
\hline & OCS5 & 0.755 & & & & \\
\hline & OCS6 & 0.841 & & & & \\
\hline & OCS7 & 0.834 & & & & \\
\hline \multirow{8}{*}{ Job stress } & JS1 & 0.765 & 0.941 & 0.95 & 0.704 & 1.184 \\
\hline & JS2 & 0.823 & & & & \\
\hline & JS3 & 0.859 & & & & \\
\hline & JS4 & 0.806 & & & & \\
\hline & JS5 & 0.831 & & & & \\
\hline & JS6 & 0.901 & & & & \\
\hline & JS7 & 0.855 & & & & \\
\hline & JS8 & 0.865 & & & & \\
\hline \multirow{10}{*}{ Leadership } & L10 & 0.754 & 0.935 & 0.944 & 0.630 & 1.322 \\
\hline & L11 & 0.72 & & & & \\
\hline & $\mathrm{L} 2$ & 0.788 & & & & \\
\hline & L3 & 0.822 & & & & \\
\hline & $\mathrm{L} 4$ & 0.813 & & & & \\
\hline & L5 & 0.774 & & & & \\
\hline & L6 & 0.834 & & & & \\
\hline & L7 & 0.823 & & & & \\
\hline & L8 & 0.868 & & & & \\
\hline & L9 & 0.73 & & & & \\
\hline \multirow{3}{*}{ Work environment } & WE1 & 0.724 & 0.774 & 0.854 & 0.596 & 1.415 \\
\hline & WE5 & 0.828 & & & & \\
\hline & WE6 & 0.829 & & & & \\
\hline \multirow{4}{*}{$\begin{array}{c}\text { Employee's job } \\
\text { satisfaction }\end{array}$} & EJS1 & 0.847 & 0.883 & 0.919 & 0.740 & \\
\hline & EJS2 & 0.854 & & & & \\
\hline & EJS3 & 0.894 & & & & \\
\hline & EJS4 & 0.845 & & & & \\
\hline
\end{tabular}

Note: $\mathrm{CA}^{1}=$ Cronbach's Alpha; $\mathrm{CR}^{2}=$ Composite Reliability; $\mathrm{AVE}^{3}=$ Average Value Extracted. 
Table 3. Discriminant validity coefficients.

\begin{tabular}{cccccc}
\hline Constructs & 1 & 2 & 3 & 4 & 5 \\
\hline EJS & $\mathbf{0 . 8 6}$ & & & & \\
JS & -0.082 & $\mathbf{0 . 8 3 9}$ & & & \\
L & 0.437 & 0.022 & $\mathbf{0 . 7 9 4}$ & $\mathbf{0 . 8 2 0}$ & $\mathbf{0 . 7 7 2}$ \\
OCS & 0.395 & 0.06 & 0.29 & 0.326 & 0.406 \\
WE & 0.514 & 0.081 &
\end{tabular}

Notes: Values on the diagonal (bold) are square root of the AVE while the off-diagonals are correlations.

Table 4. Heterotrait-Monotrait ratio (HTMT).

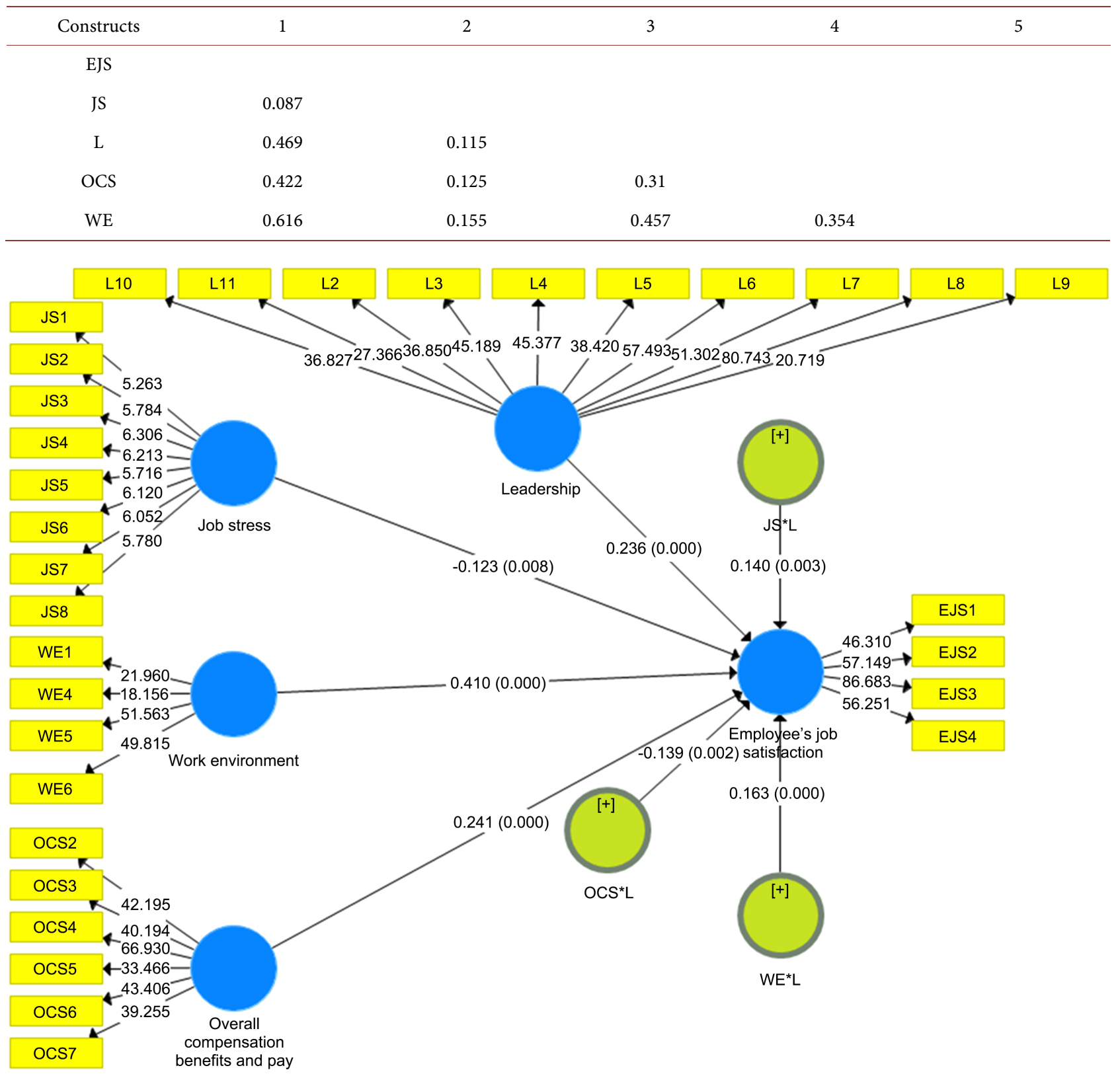

Figure 1. Structural equation modelling (path coefficient and $p$-value). 
Coefficient of determination: To evaluate the variance of the constructs, PLS-SEM suggests evaluating the $\mathrm{R}^{2}$ coefficient, which also called the coefficient of determination (Hair Jr. et al., 2011). According to (Cohen, 1998), the value of $\mathrm{R}^{2} 0.60,0.33$ and 0.19 respectively set as rule of thumb and these values are described as substantial, moderate and weak. (Hair Jr. et al., 2010) proposed that the $\mathrm{R}^{2}$ coefficient is subject to the situation where a specific study is conducted. However, as per (Falk \& Miller, 1992), recommendation $\mathrm{R}^{2}$ coefficients of 0.10 is also acceptable. Meanwhile, as reflected in Table 6 , the present study $\mathrm{R}^{2}$ noted 0.429 . The value of 0.429 indicates that $49.2 \%$ variation in EJS occurred due to JS, WE, OCS, and leadership.

Predictive relevance of the model: Keeping in view the reflective nature of measures, this study employed cross-validated redundancy measure $\mathrm{Q}^{2}$, for evaluating the model as per suggestions of (Ringle et al., 2012). It is an indicator of the model's out-of-sample predictive power or predictive relevance given by (Geisser, 1974; Stone, 1974) Q ${ }^{2}$ value. In the structural equation model, $Q^{2}$ values larger than zero for a specific reflective endogenous latent variable indicate the path model's predictive relevance for a particular dependent construct. Moreover, As a relative measure of predictive relevance, $q^{2}$ values of $0.02,0.15$, and 0.35 , respectively, indicate that an exogenous construct has a small, medium, or substantial predictive relevance for a specific endogenous construct. Hence, as reflected in Table 6 , the results of the study shows that model has substantial predictive relevance.

The Effect Sizes $(\hat{f})$ : In order to examine the $\mathrm{R}^{2}$ values of all endogenous constructs, the change in the $\mathrm{R}^{2}$ value when a specified exogenous construct is omitted from the model can be used to evaluate whether the omitted construct has a substantive impact on the endogenous constructs. This measure is mostly preferred by editors and reviewers. In addition, the values of $0.02,0.15$, and 0.35 , respectively, represent small, medium, and large effects (Cohen, 2013). If the value of $\vec{f}$ is $<0.02$, it indicates that there is no effect. The results of the study shown in Table 5 proved that there is an effect.

Testing the moderation effect. The product indicator techniques PLS-SEM was used for identifying and assessing the power of moderating effect of trust and charge/price on the service quality, effective treatment, and patient satisfaction (Chin, 2010). This study used a product indicator method because the suggested moderating construct was continuous (Rigdon et al., 1998). Furthermore, (Cohen, 1998) rules were used for assessing the moderating effects.

Recalling H5 ( $a, b$, and c), it was proposed that a leadership moderates the relationship between JS, WE, OCS, and EJS. As shown, in Table 5 and Figure 1 propose that the $\left(J S^{\star} \mathrm{L} \rightarrow \beta=0.140, \mathrm{t}\right.$-value $\left.=2.988\right),\left(\mathrm{WE}^{\star} \mathrm{L} \rightarrow \beta=0.163\right.$, $\mathrm{t}$-value $=4.094)$, and $\left(\mathrm{OCS}^{\star} \mathrm{L} \rightarrow \beta=-0.139\right.$, $\mathrm{t}$-value $\left.=3.069\right)$ interaction terms was significant. Hence, H5 (a-c) was fully supported.

Determining the strength of the moderating effects: The power of moderating effects could be evaluated by matching the $\mathrm{R}^{2}$ value of the main and $\mathrm{R}^{2}$ 
full model (Henseler \& Fassott, 2010) and the strength of moderating effects' could be assessed by employing the formula given below (Cohen, 1998):

$$
\text { Effect Size }:(f)^{2}=\frac{R^{2} \text { model with moderator }-R^{2} \text { model without moderator }}{1-R^{2} \text { model with moderator }}
$$

The values of $0.02,0.15$ and 0.35 , respectively represent as weak, moderate and strong moderating effects sizes (Cohen, 1998). As per the rule of (Cohen, 1998), the power of the moderating effect of leadership was assessed and reported in Table 6.

(Chin et al., 2003) stated that a small effect size does not necessarily mean that the causal moderating effect is irrelevant. "Even a small interaction effect can be meaningful under extreme moderating conditions, if the resulting beta changes are meaningful, then it is important to take these conditions into account" (Chin et al., 2003). This has recommended that the moderating role of leadership over JS, WE, OCS, and EJS is weak.

The slope for the relationship between JS and EJS is moderated by leadership showed that the relationship became stronger when the leadership is high. The slope is given in Figure 2.

The results shown in Figure 3 reflect that employees' who have participative leadership at work are less likely to be engaged at work. In short, WE has greater impacts on EJS. The relationship between WE and EJS is stronger when employees high participative leadership at work.

The results shown in Figure 4 reflect that employees' who have participative

Table 5. Paths coefficients and hypothesis testing.

\begin{tabular}{|c|c|c|c|c|c|c|c|}
\hline Hypothesis & Relationship & Path coefficient & Mean & SD & $t$-value & Decision & f Square \\
\hline \multicolumn{8}{|l|}{ Direct effect } \\
\hline $\mathrm{H} 1$ & JS $\rightarrow$ EJS & -0.123 & -0.121 & 0.048 & $2.64^{\star}$ & Supported & 0.022 \\
\hline $\mathrm{H} 2$ & $\mathrm{WE} \rightarrow$ EJS & 0.410 & 0.409 & 0.047 & $8.633^{*}$ & Supported & 0.203 \\
\hline $\mathrm{H} 3$ & OCS $\rightarrow$ EJS & 0.241 & 0.244 & 0.042 & $5.729^{\star}$ & Supported & 0.081 \\
\hline $\mathrm{H} 4$ & $\mathrm{~L} \rightarrow \mathrm{EJS}$ & 0.236 & 0.236 & 0.045 & $5.076^{\star}$ & Supported & 0.074 \\
\hline \multicolumn{8}{|l|}{ Direct effect } \\
\hline $\mathrm{H} 5 \mathrm{a}$ & $\mathrm{JS}^{*} \mathrm{~L} \rightarrow$ EJS & 0.140 & 0.133 & 0.047 & $2.988^{*}$ & Supported & 0.026 \\
\hline $\mathrm{H} 5 \mathrm{~b}$ & $\mathrm{WE}^{\star} \mathrm{L} \rightarrow$ EJS & 0.163 & 0.169 & 0.041 & $4.094^{\star}$ & Supported & 0.04 \\
\hline $\mathrm{H} 5 \mathrm{c}$ & $\mathrm{OCS}^{\star} \mathrm{L} \rightarrow$ EJS & -0.139 & -0.141 & 0.046 & $3.069^{\star}$ & Supported & 0.026 \\
\hline
\end{tabular}

Notes: Critical values. ${ }^{\star}$ t-value $>1.96(p<0.05)$.

Table 6. Structural model.

\begin{tabular}{ccccrcr}
\hline Model & \multicolumn{2}{c}{ Construct cross-validated redundancy } & \multicolumn{2}{c}{$\begin{array}{c}\text { Goodness of fit } \\
\text { (SRMR) }\end{array}$} \\
\hline Constructs & SSO & SSE & $\mathrm{Q}^{2}(=1$-SSE/SSO) & $\mathrm{R}^{2}$ & Adj. R \\
Employee's job satisfaction & 2060.00 & 1453.95 & 0.39 & 0.429 & 0.421 \\
\hline
\end{tabular}

Source: Researcher. 


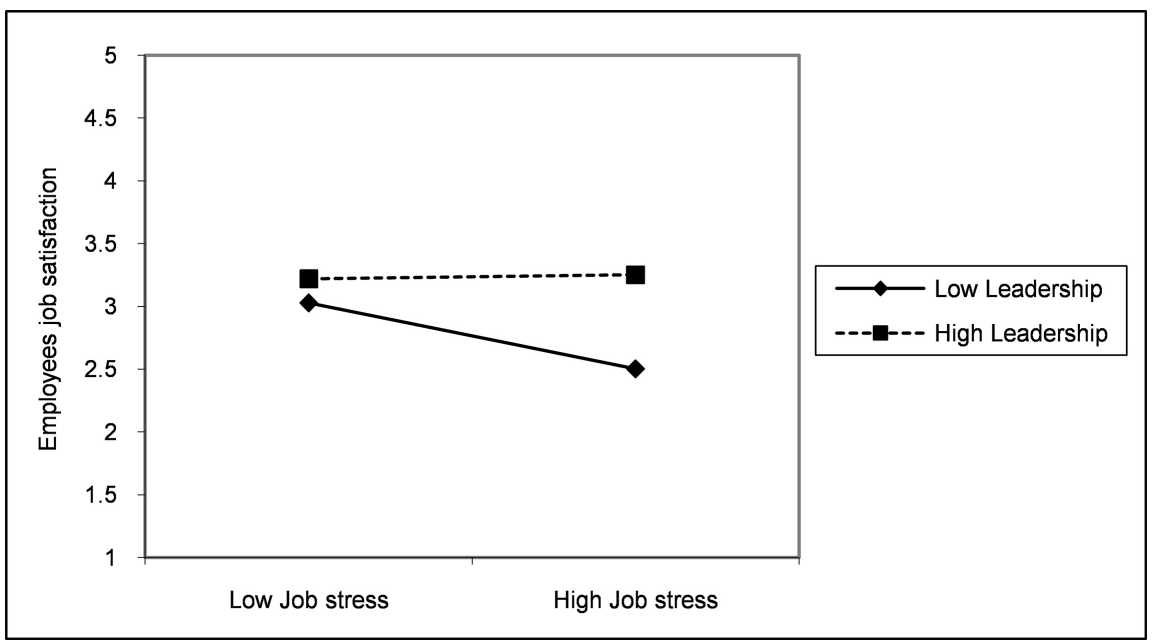

Figure 2. The slope for the interactive effect of leadership on JS and EJS.

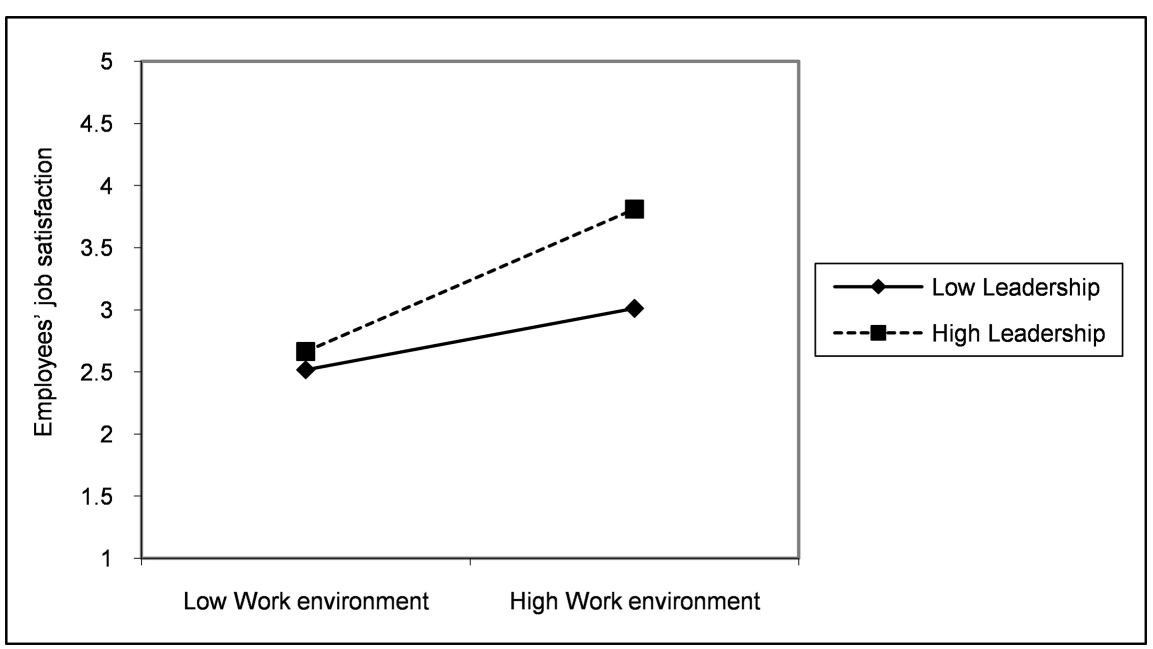

Figure 3. The slope for the interactive effect of leadership on WE and EJS.

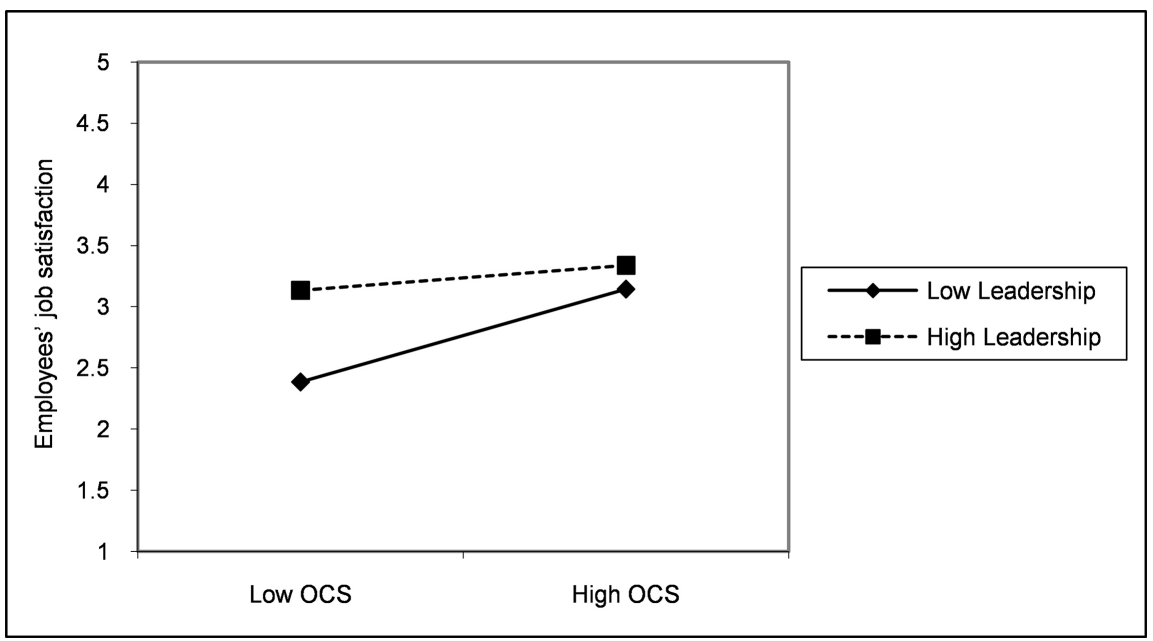

Figure 4. The slope for the interactive effect of leadership on OCS and EJS. 
leadership at work are more likely to be engaged at work. In short overall compensation benefits and pay has greater impacts on employees' job satisfaction. The positive relationship between overall compensation benefits and pay and employees job satisfaction are stronger when employees have participative leadership at work.

\section{Discussion}

The survey-based quantitative study was employed to describe the factors that influence the job satisfaction of employees working in the telecom industry of Cameron. The findings of the study are interesting, given the moderating role of participative leadership. Many different factors are used and employed by industry, which could also be instigated regarding how they support EJS, e.g. organizational culture, job engagement, commitment, etc.

The JS was found to have negative impacts on EJS $(p=0.008)$, in line with (Trivellas et al., 2013). The primary reason for negative effects includes ambiguity in role, workload, and undefined task. No doubt, that once changes occurred, some of the employees' worried about their job because of inability, less competitiveness, skills, and an increase in pressure to offer better quality in services. Such an increase in pressure gives birth to stress, which affects the employees' job satisfaction.

The WE found to be an essential factor in EJS $(p=0.001)$. These findings of the study consistent with (Pawirosumarto et al., 2017), who found positive influence of WE on EJS. The results reflected that better and comfortable the WE is in a job, the higher the level of EJS. Furthermore, an internal environment plays a vital role in is the satisfaction of the employees. For instance, when a job is well defined, the task is distributed, guidance is available from executives employees' performance will increase.

Notably, a significant relationship was found between OCS and EJS ( $p=$ 0.001). The prior research also proved that it's not mandatory compensation benefits, and pay only increases the employees' job satisfaction. Though it influences employees' job satisfaction. These findings revealed that employees are satisfied when they received equivalent level of benefits and pay. Moreover, to boost the sales team and to involve the employees at work, they must be received incentive and increase in bonuses and other benefits. These findings of the study consistent with (Husain et al., 2019; Muzailani et al., 2019).

Indeed, the significant relationship between leadership and EJS ( $p=0.001)$ demonstrated that the productivity of employees, their involvement in the work, punctuality of their timing, consistency in their work will become higher when they have role models and assistance of their leaders. This finding of the study consistent with (Chan, 2019). The participative leadership encourages subordinate to engage with work and feel satisfied with shared responsibilities and duties.

Similar participative leadership moderates the relationship between JS, WE, 
OCS, and EJS. For instance, when there is role ambiguity and less directed towards a task, employees approach the leaders. Hence, Hypothesis 5(a-c): constructed and the results found supported.

\section{Limitations and Contributions}

This study is not free from limitations. This study used convenience random sampling approach due to limited budget and time constraints and was limited to singly industry. In addition, the study considered Cameron only, which restrained the generalizability of the existing findings across different cultures. Thus, future studies should employ the across-cultural approach to examine the impacts of stress and moderation effects on employee's job satisfaction. From broader perspectives, there may be other predictors and influence factors. Consequently, the involvement of limited factors may be considered a limitation. Moreover, the model tested in single country. The outcomes represent a snapshot at a particular time but the effects of leadership are volatile over time. The industry involved only service firms, hence future research could be targeted on other industries.

This study contributes to literature in several ways. First, in preceding examinations, scholars have shown interest in the moderating effects of leadership style. (Zhu et al., 2009) stated that leadership style has moderating effects on the employee's characteristics and working conditions. This study contributes to the moderating interaction effect of participative leadership on work environment and job satisfaction. As it was proved in hypothesis 8. Leadership positively and significantly moderate the relationship.

Second, this education examines the mechanism of associations among compensation benefits and pay to work environment and job satisfaction. Herzberg's theory of motivation (1959) stated how hygiene and motivational factors influence job satisfaction and also investigated by (Addis et al., 2018). While the theory has a gap of how the work environment mediates the relationship between constructs. Hence, this study elaborates the mediating role of the work environment.

Third, this study provides aids to telecom organizations' executives about lessening the level of job stress. As it's proved that to increase the employees' job satisfaction executives are required to improve the work environment, which necessitates that there should be clarity among objectives, role, tasks, and targets. Additionally, leaders also provide them support and assistance to increase loyalty and bonding with organizations.

\section{Conflicts of Interest}

The authors declare no conflicts of interest regarding the publication of this paper.

\section{References}

Addis, S., Dvivedi, A., \& Beshah, B. (2018). Determinants of Job Satisfaction in Ethiopia: 
Evidence from the Leather Industry. African Journal of Economic and Management Studies, 9, 410-429. https://doi.org/10.1108/AJEMS-09-2017-0222

Afrizal, R. (2012). Analisis Pengaruh Gaya Kepemimpinan, Lingkungan Kerja dan Kompensasi terhadap Kepuasan Kerja Karyawan PT. Nindya Karya Persero.

Afsar, B., \& Badir, Y. (2017). Workplace Spirituality, Perceived Organizational Support and Innovative Work Behavior: The Mediating Effects of Person-Organization Fit. Journal of Workplace Learning, 29, 95-109. https://doi.org/10.1108/JWL-11-2015-0086

Agbozo, G. K., Owusu, I. S., Hoedoafia, M. A., \& Atakorah, Y. B. (2017). The Effect of Work Environment on Job Satisfaction: Evidence from the Banking Sector in Ghana. Journal of Human Resource Management, 5, 12-18. https://doi.org/10.11648/j.jhrm.20170501.12

Akter, S., Fosso Wamba, S., \& Dewan, S. (2017). Why PLS-SEM Is Suitable for Complex Modelling? An Empirical Illustration in Big Data Analytics Quality. Production Planning \& Control, 28, 1011-1021. https://doi.org/10.1080/09537287.2016.1267411

Al-Sada, M., Al-Esmael, B., \& Faisal, M. N. (2017). Influence of Organizational Culture and Leadership Style on Employee Satisfaction, Commitment and Motivation in the Educational Sector in Qatar. EuroMed Journal of Business, 12, 163-188. https://doi.org/10.1108/EMJB-02-2016-0003

Ashraf, M. A. (2019). The Mediating Role of Work Atmosphere in the Relationship between Supervisor Cooperation, Career Growth and Job Satisfaction. Journal of Workplace Learning, 31, 78-94. https://doi.org/10.1108/JWL-12-2017-0113

Attar, M., Çağliyan, V., \& Ajdarovska, Z. (2017). The Effect of Ethical Leadership on Employees' Job Satisfaction: A Study on Municipalities in Konya. Kastamonu Üniversitesi Íktisadi ve Ídari Bilimler Fakültesi Dergisi, 19, 18-35.

Audit for the Ministry of Post and Telecommunication (Minpostel) in Cameroon (2017).

Bagozzi, R. P., \& Yi, Y. (1988). On the Evaluation of Structural Equation Models. Journal of the Academy of Marketing Science, 16, 74-94. https://doi.org/10.1007/BF02723327

Barsade, S., \& O’Neill, O. A. (2016). Manage Your Emotional Culture. Harvard Business Review, 94, 14.

Başol, O. (2016). Classic or Modern? Enhancement of Job Satisfaction Scale for Green Job Workers. Management, 11, 103-122.

Bawafaa, E., Wong, C. A., \& Laschinger, H. (2015). The Influence of Resonant Leadership on the Structural Empowerment and Job Satisfaction of Registered Nurses. Journal of Research in Nursing, 20, 610-622. https://doi.org/10.1177/1744987115603441

Beehr, T. A., \& Newman, J. E. (1978). Job Stress, Employee Health, and Organizational Effectiveness: A Facet Analysis, Model, and Literature Review. Personnel Psychology, 31, 665-699. https://doi.org/10.1111/j.1744-6570.1978.tb02118.x

Beheshtifar, M., Hoseinifar, H., \& Moghadam, M. (2011). Effect Procrastination on Work-Related Stress. European Journal of Economics, Finance and Administrative Sciences, 38, 59-64.

Benoliel, P., \& Barth, A. (2017). The Implications of the School's Cultural Attributes in the Relationships between Participative Leadership and Teacher Job Satisfaction and Burnout. Journal of Educational Administration, 55, 640-656. https://doi.org/10.1108/JEA-10-2016-0116

Boamah, S. A., Laschinger, H. K. S., Wong, C., \& Clarke, S. (2018). Effect of Transformational Leadership on Job Satisfaction and Patient Safety Outcomes. Nursing Outlook, 66, 180-189. https://doi.org/10.1016/j.outlook.2017.10.004 
Borgwardt, F., Robinson, L., Trauner, D., Teixeira, H., Nogueira, A. J., Lillebø, A. I. et al. (2019). Exploring Variability in Environmental Impact Risk from Human Activities across Aquatic Ecosystems. Science of the Total Environment, 652, 1396-1408. https://doi.org/10.1016/j.scitotenv.2018.10.339

Bortoluzzi, G., Caporale, L., \& Palese, A. (2014). Does Participative Leadership Reduce the Onset of Mobbing Risk among Nurse Working Teams? Journal of Nursing Management, 22, 643-652. https://doi.org/10.1111/jonm.12042

Çetinkaya, F., \& Karabulut, N. (2016). Validity and Reliability of the Turkish Version of the Visual Analog Sleep Scale. Kontakt, 18, e84-e89. https://doi.org/10.1016/j.kontakt.2016.05.003

Chaiprasit, K., \& Santidhiraku, O. (2011). Happiness at Work of Employees in Small and Medium-Sized Enterprises, Thailand. Procedia-Social and Behavioral Sciences, 25, 189-200. https://doi.org/10.1016/j.sbspro.2011.10.540

Chan, J. H., Chan, D. W., Chan, A. P., Lam, P. T., \& Yeung, J. F. (2011). Developing a Fuzzy Risk Assessment Model for Guaranteed Maximum Price and Target Cost Contracts in Construction. Journal of Facilities Management, 9, 34-51. https://doi.org/10.1108/14725961111105709

Chan, S. C. (2019). Participative Leadership and Job Satisfaction. Leadership \& Organization Development Journal, 40, 319-333. https://doi.org/10.1108/LODJ-06-2018-0215

Chin, W. W. (2010). How to Write Up and Report PLS Analyses. In V. Esposito Vinzi, W. Chin, J. Henseler, \& H. Wang (Eds.), Handbook of Partial Least Squares (pp. 655-690). Berlin, Heidelberg: Springer. https://doi.org/10.1007/978-3-540-32827-8_29

Chin, W. W., Marcolin, B. L., \& Newsted, P. R. (2003). A Partial Least Squares Latent Variable Modeling Approach for Measuring Interaction Effects: Results from a Monte Carlo Simulation Study and an Electronic-Mail Emotion/Adoption Study. Information Systems Research, 14, 189-217. https://doi.org/10.1287/isre.14.2.189.16018

Chinyio, E., Suresh, S., \& Salisu, J. B. (2018). The Impacts of Monetary Rewards on Public Sector Employees in Construction: A Case of Jigawa State in Nigeria. Journal of Engineering, Design and Technology, 16, 125-142. https://doi.org/10.1108/JEDT-12-2016-0098

Choshin, M., \& Ghaffari, A. (2017). An Investigation of the Impact of Effective Factors on the Success of E-Commerce in Small- and Medium-Sized Companies. Computers in Human Behavior, 66, 67-74. https://doi.org/10.1016/j.chb.2016.09.026

Chung, E. K., Jung, Y., \& Sohn, Y. W. (2017). A Moderated Mediation Model of Job Stress, Job Satisfaction, and Turnover Intention for Airport Security Screeners. Safety Science, 98, 89-97. https://doi.org/10.1016/j.ssci.2017.06.005

Cohen, J. (1998). Statistical Power Analysis for the Behavioural Sciences (xxi). Hillsdale, NJ: Lawrence Erlbaum Associates Inc.

Cohen, J. (2013). Statistical Power Analysis for the Behavioral Sciences. Abingdon-onThames: Routledge.

Curşeu, P. L. (2011). Intra-Group Conflict and Teamwork Quality: The Moderating Role of Leadership Styles. Administrative Sciences, 1, 3-13. https://doi.org/10.3390/admsci1010003

Day, A., Crown, S. N., \& Ivany, M. (2017). Organisational Change and Employee Burnout: The Moderating Effects of Support and Job Control. Safety Science, 100, 4-12. https://doi.org/10.1016/j.ssci.2017.03.004

De Jonge, J., Bosma, H., Peter, R., \& Siegrist, J. (2000). Job Strain, Effort-Reward Imbalance and Employee Well-Being: A Large-Scale Cross-Sectional Study. Social Science \& 
Medicine, 50, 1317-1327. https://doi.org/10.1016/S0277-9536(99)00388-3

de Oliveira, L. B., Cavazotte, F., \& Alan Dunzer, R. (2019). The Interactive Effects of Organizational and Leadership Career Management Support on Job Satisfaction and Turnover Intention. The International Journal of Human Resource Management, 30, 1583-1603. https://doi.org/10.1080/09585192.2017.1298650

De Simone, S., Cicotto, G., \& Lampis, J. (2016). Occupational Stress, Job Satisfaction and Physical Health in Teachers. European Review of Applied Psychology, 66, 65-77. https://doi.org/10.1016/j.erap.2016.03.002

Dhamija, P., Gupta, S., \& Bag, S. (2019). Measuring of Job Satisfaction: The Use of Quality of Work Life Factors. Benchmarking: An International Journal, 26, 871-892. https://doi.org/10.1108/BIJ-06-2018-0155

Doeleman, H., ten Have, S., \& Ahaus, K. (2012). The Moderating Role of Leadership in the Relationship between Management Control and Business Excellence. Total Quality Management \& Business Excellence, 23, 591-611. https://doi.org/10.1080/14783363.2012.669935

Donkin, C. (2019). Cameroon Slaps Fines on Largest Operators.

Dutra, H. S., Cimiotti, J. P., \& de Brito Guirardello, E. (2018). Nurse Work Environment and Job-Related Outcomes in Brazilian Hospitals. Applied Nursing Research, 41, 68-72. https://doi.org/10.1016/j.apnr.2018.04.002

Eikelenboom, M., \& de Jong, G. (2019). The Impact of Dynamic Capabilities on the Sustainability Performance of SMEs. Journal of Cleaner Production, 235, 1360-1370. https://doi.org/10.1016/j.jclepro.2019.07.013

Eiriz, V., \& Carreiras, J. (2018). Change in Supply Networks: A Case Study in the Automotive Components Industry. Management Decision, 56, 922-936. https://doi.org/10.1108/MD-03-2017-0219

Falk, R. F., \& Miller, N. B. (1992). A Primer for Soft Modeling. Akron, OH: University of Akron Press.

Filtvedt, R. E. (2016). Motivation and Job Satisfaction: Does Herzberg's "Two-Factor" Theory Apply to Knowledge Workers of Today? Ås, Norway: Norwegian University of Life Sciences.

Fornell, C., \& Larcker, D. F. (1981). Evaluating Structural Equation Models with Unobservable Variables and Measurement Error. Journal of Marketing Research, 18, 39-50. https://doi.org/10.1177/002224378101800104

Gacevic, M., Milicevic, M. S., Vasic, M., Horozovic, V., Milicevic, M., \& Milic, N. (2018). The Relationship between Dual Practice, Intention to Work Abroad and Job Satisfaction: A Population-Based Study in the Serbian Public Healthcare Sector. Health Policy, 122, 1132-1139. https://doi.org/10.1016/j.healthpol.2018.09.004

Geisser, S. (1974). A Predictive Approach to the Random Effect Model. Biometrika, 61, 101-107. https://doi.org/10.1093/biomet/61.1.101

Gold, A. H., Malhotra, A., \& Segars, A. H. (2001). Knowledge Management: An Organizational Capabilities Perspective. Journal of Management Information Systems, 18, 185-214. https://doi.org/10.1080/07421222.2001.11045669

González-Navarro, P., Zurriaga-Llorens, R., Tosin Olateju, A., \& Llinares-Insa, L. (2018). Envy and Counterproductive Work Behavior: The Moderation Role of Leadership in Public and Private Organizations. International Journal of Environmental Research and Public Health, 15, 1455. https://doi.org/10.3390/ijerph15071455

Guidetti, G., Converso, D., Loera, B., \& Viotti, S. (2018). Concerns about Change and 
Employee Wellbeing: The Moderating Role of Social Support. Journal of Workplace Learning, 30, 216-228. https://doi.org/10.1108/JWL-09-2017-0083

Gulyani, G., \& Sharma, T. (2018). Total Rewards Components and Work Happiness in New Ventures: The Mediating Role of Work Engagement. Evidence-Based HRM, 6, 255-271. https://doi.org/10.1108/EBHRM-12-2017-0063

Hair Jr., J. F., Black, W. C., Babin, B. J., \& Anderson, R. E. (2010). Multivariate Data Analysis: Global Edition. Upper Saddle River, NJ: Pearson Higher Education.

Hair Jr., J. F., Hult, G. T. M., Ringle, C., \& Sarstedt, M. (2016). A Primer on Partial Least Squares Structural Equation Modeling (PLS-SEM). Thousand Oaks, CA: Sage Publications.

Hair Jr., J. F., Ringle, C. M., \& Sarstedt, M. (2011). PLS-SEM: Indeed a Silver Bullet. Journal of Marketing Theory and Practice, 19, 139-152. https://doi.org/10.2753/MTP1069-6679190202

Hair Jr., J. F., Sarstedt, M., Pieper, T. M., \& Ringle, C. M. (2012a). The Use of Partial Least Squares Structural Equation Modeling in Strategic Management Research: A Review of Past Practices and Recommendations for Future Applications. Long Range Planning, 45, 320-340. https://doi.org/10.1016/j.lrp.2012.09.008

Hair Jr., J. F., Sarstedt, M., Ringle, C. M., \& Mena, J. A. (2012b). An Assessment of the Use of Partial Least Squares Structural Equation Modeling in Marketing Research. Journal of the Academy of Marketing Science, 40, 414-433. https://doi.org/10.1007/s11747-011-0261-6

Hair Jr., J. F., Sarstedt, M., Ringle, C. M., \& Gudergan, S. P. (2017). Advanced Issues in Partial Least Squares Structural Equation Modeling. Thousand Oaks, CA: Sage Publications.

Halkos, G., \& Bousinakis, D. (2017). The Effect of Stress and Dissatisfaction on Employees during Crisis. Economic Analysis and Policy, 55, 25-34. https://doi.org/10.1016/j.eap.2017.04.002

Hamid, Z., \& Azhar, S. M. (2015). The Impact of Strategic HRM Practices on Employee's Job Satisfaction: The Moderating Effect of Transformational Leadership. World Academy of Science, Engineering and Technology, International Journal of Social, Behavioral, Educational, Economic, Business and Industrial Engineering, 8, 3400-3404.

Harris, S. (2018). The Trillion Dollar Race: What 5 G Means to the Global Economy.

Henseler, J., \& Fassott, G. (2010). Testing Moderating Effects in PLS Path Models: An Illustration of Available Procedures. In V. Esposito Vinzi, W. Chin, J. Henseler, \& H. Wang (Eds.), Handbook of Partial Least Squares (pp. 713-735). Berlin, Heidelberg: Springer. https://doi.org/10.1007/978-3-540-32827-8_31

Henseler, J., Ringle, C. M., \& Sinkovics, R. R. (2009). The Use of Partial Least Squares Path Modeling in International Marketing. In R. R. Sinkovics, \& P. N. Ghauri (Eds.), New Challenges to International Marketing (pp. 277-319). Bingley: Emerald Group Publishing Limited. https://doi.org/10.1108/S1474-7979(2009)0000020014

Holland, P., Sheehan, C., \& De Cieri, H. (2007). Attracting and Retaining Talent: Exploring Human Resources Development Trends in Australia. Human Resource Development International, 10, 247-262. https://doi.org/10.1080/13678860701515158

Huang, X., Shi, K., Zhang, Z., \& Cheung, Y. L. (2006). The Impact of Participative Leadership Behavior on Psychological Empowerment and Organizational Commitment in Chinese State-Owned Enterprises: The Moderating Role of Organizational Tenure. Asia Pacific Journal of Management, 23, 345-367.

https://doi.org/10.1007/s10490-006-9006-3 
Husain, R., Seputro, A., \& Paramita, P. D. (2019). The Effect of Compensation, Work Environment and Work Loads on Work Satisfaction and Its Impact on Employee Loyalty of Production Part CV. Bahari Tegal Bakery. Journal of Management, 5, 1-10.

Hussain, T., \& Younis, A. (2015). Quality Management Practices and Organizational Performance: Moderating Role of Leadership. Science International, 27, 517-522.

Ilies, R., \& Judge, T. A. (2004). An Experience-Sampling Measure of Job Satisfaction and Its Relationships with Affectivity, Mood at Work, Job Beliefs, and General Job Satisfaction. European Journal of Work and Organizational Psychology, 13, 367-389. https://doi.org/10.1080/13594320444000137

Jibril, A. B., Kwarteng, M. A., Pilik, M., Botha, E., \& Osakwe, C. N. (2020). Towards Understanding the Initial Adoption of Online Retail Stores in a Low Internet Penetration Context: An Exploratory Work in Ghana. Sustainability, 12, 854.

https://doi.org/10.3390/su12030854

Jin, X., Sun, I. Y., Jiang, S., Wang, Y., \& Wen, S. (2018). The Relationships between Job and Organizational Characteristics and Role and Job Stress among Chinese Community Correctional Workers. International Journal of Law, Crime and Justice, 52, 36-46. https://doi.org/10.1016/j.ijlcj.2017.09.002

Kakada, P., \& Deshpande, Y. (2019). Working Conditions and Effective Supervision: Does It Matter for Engineering Faculty Job Satisfaction. The International Journal of Electrical Engineering \& Education. https://doi.org/10.1177/0020720918815998

Karimi, K. L. (2019). Effects of Business Mergers on Employee Loyalty in Selected Companies Listed at the Nairobi Securities Exchange. Global Journal of Management And Business Research, 19, 41-46.

Khalatbari, J., Ghorbanshiroudi, S., \& Firouzbakhsh, M. (2013). Correlation of Job Stress, Job Satisfaction, Job Motivation and Burnout and Feeling Stress. Procedia-Social and Behavioral Sciences, 84, 860-863. https://doi.org/10.1016/j.sbspro.2013.06.662

Khamisa, N., Peltzer, K., Ilic, D., \& Oldenburg, B. (2017). Effect of Personal and Work Stress on Burnout, Job Satisfaction and General Health of Hospital Nurses in South Africa. Health SA Gesondheid, 22, 252-258. https://doi.org/10.1016/j.hsag.2016.10.001

Khoi, B. H., \& Van Tuan, N. (2018). Using SmartPLS 3.0 to Analyse Internet Service Quality in Vietnam. In L. Anh, L. Dong, V. Kreinovich, \& N. Thach (Eds.), International Econometric Conference of Vietnam, 2018 (pp. 430-439). Berlin: Springer. https://doi.org/10.1007/978-3-319-73150-6_34

Kim, N.-S., Yoon, N.-N., Kim, Y.-H., Park, J.-H., Kim, H.-J., \& Lee, J.-H. (2018). The Effect of Dental Hygienist's Work Environment on Job Satisfaction and Organizational Commitment. Journal of Korean Society of Dental Hygiene, 18, 153-164. https://doi.org/10.13065/jksdh.2018.18.02.153

Kock, N., \& Hadaya, P. (2018). Minimum Sample Size Estimation in PLS-SEM: The Inverse Square Root and Gamma-Exponential Methods. Information Systems Journal, 28, 227-261.

Kura, K. M. (2016). Linking Environmentally Specific Transformational Leadership and Environmental Concern to Green Behaviour at Work. Global Business Review, 17, 1S-14S. https://doi.org/10.1177/0972150916631069

Lambert, E. G., Qureshi, H., Frank, J., Klahm, C., \& Smith, B. (2018). Job Stress, Job Involvement, Job Satisfaction, and Organizational Commitment and Their Associations with Job Burnout among Indian Police Officers: A Research Note. Journal of Police and Criminal Psychology, 33, 85-99. https://doi.org/10.1007/s11896-017-9236-y

Lancaster, H. (2019). Cameroon-Telecoms, Mobile and Broadband-Statistics and 
Analyses.

Langer, J., Feeney, M. K., \& Lee, S. E. (2019). Employee Fit and Job Satisfaction in Bureaucratic and Entrepreneurial Work Environments. Review of Public Personnel Administration, 39, 135-155. https://doi.org/10.1177/0734371X17693056

Lee, C.-H., \& Moon, J. (2011). Effects of Officers' Cynicism and Their Perception of Managerial Leadership on COP Activities among South Korean Police Officers. Policing: An International Journal of Police Strategies \& Management, 34, 31-48. https://doi.org/10.1108/13639511111106597

Lee, J.-S., Back, K.-J., \& Chan, E. S. (2015). Quality of Work Life and Job Satisfaction among Frontline Hotel Employees. International Journal of Contemporary Hospitality Management, 27, 768-789. https://doi.org/10.1108/IJCHM-11-2013-0530

Lim, S., Lee, K.-H., \& Bae, K.-H. (2019). Distinguishing Motivational Traits between Person-Organization Fit and Person-Job Fit: Testing the Moderating Effects of Extrinsic Rewards in Enhancing Public Employee Job Satisfaction. International Journal of Public Administration, 42, 1040-1054. https://doi.org/10.1080/01900692.2019.1575665

Locke, E. A. (1976). The Nature and Causes of Job Satisfaction. In M. D. Dunnette (Ed.), Handbook of Industrial and Organizational Psychology. Chicago, IL: Rand McNally.

Lu, H., Barriball, K. L., Zhang, X., \& While, A. E. (2012). Job Satisfaction among Hospital Nurses Revisited: A Systematic Review. International Journal of Nursing Studies, 49, 1017-1038. https://doi.org/10.1016/j.ijnurstu.2011.11.009

Lyons, F. H., \& Ben-Ora, D. (2002). Total Rewards Strategy: The Best Foundation of Pay for Performance. Compensation \& Benefits Review, 34, 34-40.

https://doi.org/10.1177/0886368702034002006

Makola, L., Mashegoane, S., \& Debusho, L. K. (2015). Work-Family and Family-Work Conflicts amongst African Nurses Caring for Patients with AIDS. Curationis, 38, a1436. https://doi.org/10.4102/curationis.v38i1.1436

Matei, M.-C., \& Abrudan, M.-M. (2016). Adapting Herzberg's Two Factor Theory to the Cultural Context of Romania. Procedia-Social and Behavioral Sciences, 221, 95-104. https://doi.org/10.1016/j.sbspro.2016.05.094

McDonald, R. P. (1996). Path Analysis with Composite Variables. Multivariate Behavioral Research, 31, 239-270. https://doi.org/10.1207/s15327906mbr3102_5

McVeigh, J., MacLachlan, M., Vallières, F., Hyland, P., Stilz, R., Cox, H. et al. (2019). Identifying Predictors of Stress and Job Satisfaction in a Sample of Merchant Seafarers Using Structural Equation Modeling. Frontiers in Psychology, 10, 70. https://doi.org/10.3389/fpsyg.2019.00070

Miao, Q., Newman, A., Schwarz, G., \& Xu, L. (2013). Participative Leadership and the Organizational Commitment of Civil Servants in China: The Mediating Effects of Trust in Supervisor. British Journal of Management, 24, S76-S92.

https://doi.org/10.1111/1467-8551.12025

Monga, A., Verma, N., \& Monga, O. (2015). A Study of Job Satisfaction of Employees of ICICI Bank in Himachal Pradesh. Human Resource Management Research, 5, 18-25.

Munir, R. I. S., \& Rahman, R. A. (2016). Determining Dimensions of Job Satisfaction Using Factor Analysis. Procedia Economics and Finance, 37, 488-496. https://doi.org/10.1016/S2212-5671(16)30156-3

Muzailani, I., Fathoni, A., \& Hasiholan, L. B. (2019). Effect of Compensation, Work Environment and Leadership on Work Satisfaction and Its Impact on Employee Loyalty in CV. Trendys Advertising Tegal. Journal of Management, 5, 1-11.

Newman, A., Rose, P. S., \& Teo, S. T. (2016). The Role of Participative Leadership and 
Trust-Based Mechanisms in Eliciting Intern Performance: Evidence from China. $\mathrm{Hu}$ man Resource Management, 55, 53-67. https://doi.org/10.1002/hrm.21660

Nunnally, J. (1978). Psychometric Methods. New York: McGraw-Hill.

Nystrom, P. C. (1990). Vertical Exchanges and Organizational Commitments of American business Managers. Group \& Organization Studies, 15, 296-312. https://doi.org/10.1177/105960119001500305

Pawirosumarto, S., Sarjana, P. K., \& Gunawan, R. (2017). The Effect of Work Environment, Leadership Style, and Organizational Culture towards Job Satisfaction and Its Implication towards Employee Performance In Parador Hotels and Resorts, Indonesia. International Journal of Law and Management, 59, 1337-1358.

https://doi.org/10.1108/IJLMA-10-2016-0085

Peluso, A. M., Innocenti, L., \& Pilati, M. (2017). Pay Is Not Everything: Differential Effects of Monetary and Non-Monetary Rewards on Employees' Attitudes and Behaviours. Evidence-Based HRM, 5, 311-327. https://doi.org/10.1108/EBHRM-07-2015-0031

Pepra-Mensah, J., Adjei, L. N., \& Agyei, A. (2017). Effect of Compensation on Basic School Teachers' Job Satisfaction in the Northern Zone: The Case of Ghana. Global Journal of Management And Business Research, 17, 51-59.

Podsakoff, P. M., MacKenzie, S. B., Lee, J.-Y., \& Podsakoff, N. P. (2003). Common Method Biases in Behavioral Research: A Critical Review of the Literature and Recommended Remedies. Journal of Applied Psychology, 88, 879-903. https://doi.org/10.1037/0021-9010.88.5.879

Qalati, S., Yuan, L., Iqbal, S., Hussain, R., \& Ali, S. (2019). Impact of Price on Customer Satisfaction; Mediating Role of Consumer Buying Behaviour in Telecom Sector. International Journal of Research, 6, 150-165.

Qureshi, I., Jamil, R., Iftikhar, M., Arif, S., Lodhi, S., Naseem, I. et al. (2012). Job Stress, Workload, Environment and Employees Turnover Intentions: Destiny or Choice. Archives of Sciences (Sciences Des Archives), 65, 230-241.

Rigdon, E. E., Schumacker, R. E., \& Wothke, W. (1998). A Comparative Review of Interaction and Nonlinear Modeling. In R. E. Schumacker (Ed.), Interaction and Nonlinear Effects in Structural Equation Modeling (pp. 1-16). New York: Routledge. https://doi.org/10.4324/9781315092614-1

Ringle, C. M., Sarstedt, M., \& Straub, D. (2012). A Critical Look at the Use of PLS-SEM in MIS Quarterly. MIS Quarterly, 36, iii-xiv. https://doi.org/10.2307/41410402

Ringle, C. M., Wende, S., \& Becker, J.-M. (2015). SmartPLS 3. Boenningstedt: SmartPLS $\mathrm{GmbH}$.

Sadalia, I., Daulay, I. E., Marlina, L., \& Muda, I. (2019). The Influence of Intellectual Capital towards Financial Performance with Brand Value as an Intervening Variable. Quality, 20, 79-85.

Scully, J. A., Kirkpatrick, S. A., \& Locke, E. A. (1995). Locus of Knowledge as a Determinant of the Effects of Participation on Performance, Affect, and Perceptions. Organizational Behavior and Human Decision Processes, 61, 276-288. https://doi.org/10.1006/obhd.1995.1022

Selye, H. (1964). From Dream to Discovery. New York: McGraw-Hill.

Singh, R., \& Nayak, J. K. (2015). Mediating Role of Stress between Work-Family Conflict and Job Satisfaction among the Police Officials: Moderating Role of Social Support. Policing: An International Journal of Police Strategies \& Management, 38, 738-753. https://doi.org/10.1108/PIJPSM-03-2015-0040 
Smylie, M. A., Lazarus, V., \& Brownlee-Conyers, J. (1996). Instructional Outcomes of School-Based Participative Decision Making. Educational Evaluation and Policy Analysis, 18, 181-198. https://doi.org/10.3102/01623737018003181

Spencer, E. S., Deal, A. M., Pruthi, N. R., Gonzalez, C. M., Kirby, E. W., Langston, J. et al. (2016). Gender Differences in Compensation, Job Satisfaction and Other Practice Patterns in Urology. The Journal of Urology, 195, 450-455.

https://doi.org/10.1016/j.juro.2015.08.100

Stamolampros, P., Korfiatis, N., Chalvatzis, K., \& Buhalis, D. (2019). Job Satisfaction and Employee Turnover Determinants in High Contact Services: Insights from Employees' Online Reviews. Tourism Management, 75, 130-147. https://doi.org/10.1016/j.tourman.2019.04.030

Stone, M. (1974). Cross-Validatory Choice and Assessment of Statistical Predictions. Journal of the Royal Statistical Society: Series B (Methodological), 36, 111-133. https://doi.org/10.1111/j.2517-6161.1974.tb00994.x

Suttikun, C., Chang, H. J., \& Bicksler, H. (2018). A Qualitative Exploration of Day Spa Therapists' Work Motivations and Job Satisfaction. Journal of Hospitality and Tourism Management, 34, 1-10. https://doi.org/10.1016/j.jhtm.2017.10.013

TELCOMA (2019). List of Mobile Network Operators of Cameroon.

Thatcher, J. B., Liu, Y., \& Stepina, L. P. (2002). The Role of the Work Itself: An Empirical Examination of Intrinsic Motivation's Influence on IT Workers Attitudes and Intentions. In Proceedings of the 2002 ACM SIGCPR Conference on Computer Personnel Research, 2002 (pp. 25-33). New York, NY: Association for Computing Machinery. https://doi.org/10.1145/512360.512365

Tomaževič, N., Seljak, J., \& Aristovnik, A. (2014). Factors Influencing Employee Satisfaction in the Police Service: The Case of Slovenia. Personnel Review, 43, 209-227. https://doi.org/10.1108/PR-10-2012-0176

Tran, M., Pham, T., Phan, T., Hoang, T., Do, D., \& Dinh, T. (2019). Factors Influencing Independent Audit Fees: Multi-Group Analysis PLS-SEM and Moderate Model. Management Science Letters, 9, 1599-1608. https://doi.org/10.5267/j.msl.2019.5.027

Trivellas, P., Reklitis, P., \& Platis, C. (2013). The Effect of Job Related Stress on Employees' Satisfaction: A Survey in Health Care. Procedia-Social and Behavioral Sciences, 73, 718-726. https://doi.org/10.1016/j.sbspro.2013.02.110

Umrani, W. A., Kura, K. M., \& Ahmed, U. (2018). Corporate Entrepreneurship and Business Performance: The Moderating Role of Organizational Culture in Selected Banks in Pakistan. PSU Research Review, 2, 59-80. https://doi.org/10.1108/PRR-12-2016-0011

Velmurugan, T. A., \& Sankar, J. G. (2017). A Comparative Study on Motivation Theory with Maslow's Hierarchy Theory and Two-Factor Theory in Organization. Indo-Iranian Journal of Scientific Research, 1, 204-208.

Wei, H., Sewell, K. A., Woody, G., \& Rose, M. A. (2018). The State of the Science of Nurse Work Environments in the United States: A Systematic Review. International Journal of Nursing Sciences, 5, 287-300. https://doi.org/10.1016/j.ijnss.2018.04.010

Welcome to Orange Cameroon (2017).

Yaoundé (2019). Cameroon: Orange and MTN Monopolise 93.8\% of the Telephone Market. Business in Cameroon.

Zhang, L.-F., You, L.-M., Liu, K., Zheng, J., Fang, J.-B., Lu, M.-M. et al. (2014). The Association of Chinese Hospital work Environment with Nurse Burnout, Job Satisfaction, and Intention to Leave. Nursing Outlook, 62, 128-137. 
https://doi.org/10.1016/j.outlook.2013.10.010

Zheng, Y., Graham, L., Epitropaki, O., \& Snape, E. (2019). Service Leadership, Work Engagement, and Service Performance: The Moderating Role of Leader Skills. Group \& Organization Management, 45, 43-74. https://doi.org/10.1177/1059601119851978

Zhu, W., Avolio, B. J., \& Walumbwa, F. O. (2009). Moderating Role of Follower Characteristics with Transformational Leadership and Follower Work Engagement. Group \& Organization Management, 34, 590-619. https://doi.org/10.1177/1059601108331242

Zulfiqar, A., Khan, N. U., Afaq, Q., \& Khan, S. (2013). Evaluating the Relationship between Work Family Conflict and Job Satisfaction (A Survey of Nursing Staff in Public Sector Hospitals of Bhakkar District). Gomal University Journal of Research, 29, 128-133. 